Discussion Paper No. 604

CORRUPTION AND ITS ALTERNATIVES:

A TAKEOFF THEORY OF GOOD GOVERNANCE

\author{
Evan Osborne
}

May 2004

The Institute of Social and Economic Research

Osaka University

6-1 Mihogaoka, Ibaraki, Osaka 567-0047, Japan 


\title{
Corruption and Its Alternatives: A Takeoff Theory of Good Governance
}

\author{
Evan Osborne \\ Wright State U. Dept. of Economics and Osaka U. Institute of Social and Economic \\ Research \\ 3640 Col. Glenn Hwy. \\ Dayton, $\mathrm{OH} 45435$ \\ (937) 7754599 \\ (937) 7752441 (Fax) \\ evan.osborne@wright.edu
}




\begin{abstract}
$\underline{\text { Abstract }}$
Corruption is a function of its return relative to engaging in productive activities. This paper presents an approach for thinking about the institutional features of societies and the resulting amount of corruption. The empirical results suggest that political competition is more important than competition in information-producing industries. The rent-seeking view of the relation between government and corruption is rejected in favor of the Becker (1983) model of political competition. The paper suggests that societies that continually stay open to productivity-enhancing activities will eventually enter a takeoff stage of anti-corruption efforts analogous to the eventual improvement in income distribution that occurs in successful industrialization.
\end{abstract}


Corruption is a topic that has soared in importance in the development community in recent years. Its role as an impediment to modernization has been empirically documented by Mo (2001) and Mauro (1995). Its capacity to distort public resource-use decisions has been demonstrated by Tanzi and Davoodi (2000), and has been interpreted as rent-seeking by Krueger (1974). Its endogenous generation has been traced in Mohtadi and Roe (2003) and Barreto (2000). Another influential theoretical approach has been that of Murphy, Shleifer and Vishny (1993, hereafter MSV), who in the Hirshleifer (1991) tradition depict the amount of rent-seeking as a function of the relative return to appropriative as opposed to productive activity.

The relation between technological progress and corruption is one that merits more study. This relation, suggested by but not explicitly explored in earlier work, has powerful implications for corruption control. It suggests that policies that increase productivity can endogenously control corruption by decreasing the desirability of producing rent-seeking opportunities. This paper derives precise conditions whereby progress in productive technology makes corruption control more worthwhile, and tests whether these conditions hold. The empirical results allow for re-interpretation of the expected effectiveness of corruption control at various stages of development. Sections 1 and 2 explore endogenous corruption where production is available as an alternative, Section 3 tests the model and Section 4 re-interprets corruption control in light of the findings.

\section{The returns to parasitism}

One empirical fact about corruption readily suggests itself - that it is inversely 
related to a nation's per capita income. Figure 1 plots the 2003 ratings of the anticorruption group Transparency International - ranging from zero to ten, with zero the most corrupt - against per capita income in 2000, obtained from the World Bank's World Development Indicators database. The relationship is somewhat concave, with a regression of the TI score on per capita GDP and per capita GDP squared included for comparison. ${ }^{1}$ Rich countries are corrupt, poor ones are not, and there are a striking number of countries with almost minimal per capita income and high degrees of corruption. Roughly half the countries in the world, in other words, are in a low-income, high-corruption equilibrium, one of two outcomes predicted by the MSV model. The relation between income and corruption has been explored empirically by Paldam (2002) using a single-equation model.

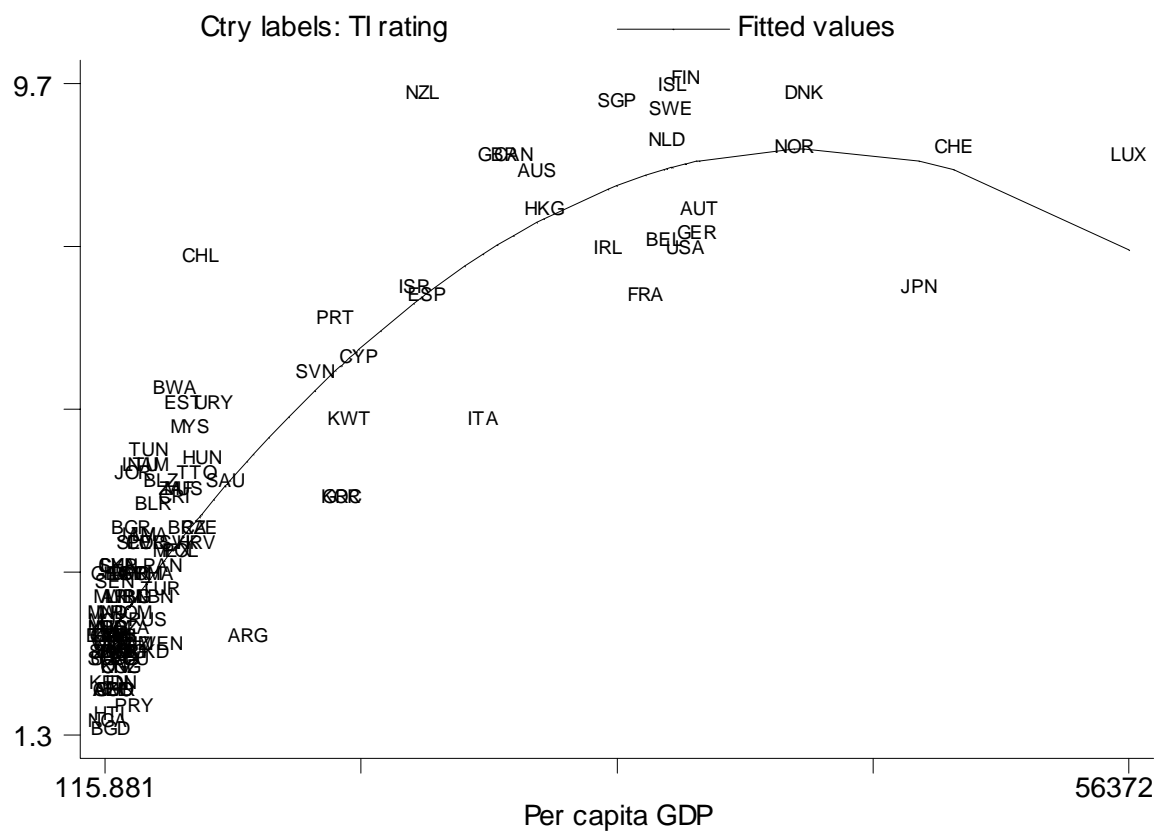

Figure 1: Corruption and per capita income.

1. The regression is $2.484125+0.0003286 P C G D P-4.23 E-09 P C G D P^{2}(n=122, F=$ $322.50, R^{2}=0.8247$ 
The traditional explanation for this relationship is that corruption destroys growth, so that fighting corruption is causally prior to successful industrialization. But suppose the reverse is true - that growth causes corruption reduction. As societies become more productive, $^{2}$ it is conceivable that a unit of resources devoted to appropriation becomes more costly. If so, the members of society may find it less attractive or be willing to endure a greater burden to fight it.

A tantalizing hint of that possibility is depicted in figure 2. The vertical axis is the 1996 TI rating, and the horizontal axis shows Solow residuals for a production function based on Penn World Tables data of the logarithm of GDP on the logarithms of the capital stock and workers in the country. A fitted line of the regression of the rating on the residual is also included, and the correlation between the residual and the TI rating is $0.4222 .^{3}$ Productivity is not the sole determinant of corruption, but it may matter in important ways.

2. The term "productivity" will denote the return to resources used in income production rather than appropriation, unless otherwise noted.

3. The regression depicted is $R A T I N G=1.5846+.0733$ RESID $\left(p<.007, R^{2}=0.1782, N\right.$ =39), where RESID is a residual calculated from a standard Solow growth regression. That regression is $L O G Q=3.5873+0.6456 L O G K+0.3309 L O G L\left(R^{2}=0.9542, N=\right.$ 60 , both variables significant at $p=0.001) . K$ is nonresidential capital per worker, and $L$ is the number of workers in the population (calculated using the figure from PWT 5.6 on the percentage of workers in the population). 


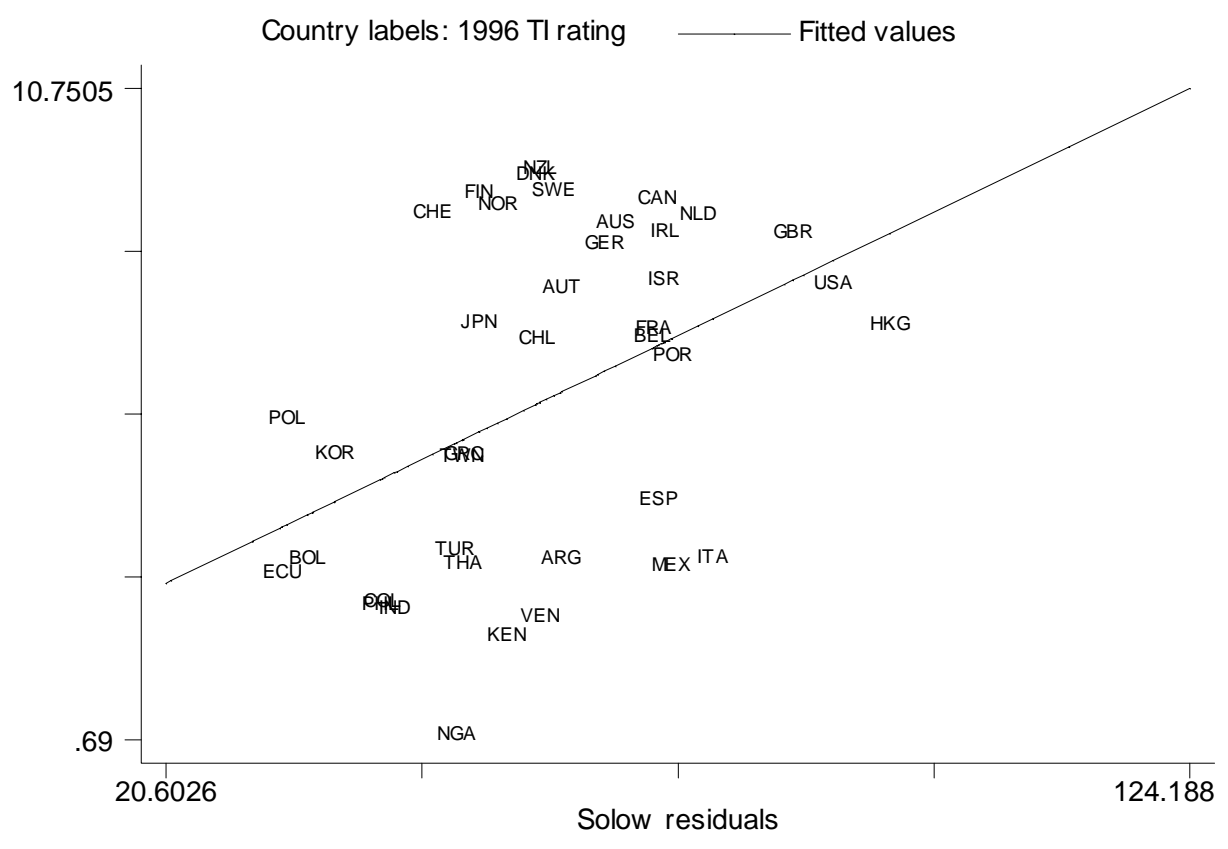

Figure 2 - Corruption and productivity.

The argument can be simply illustrated. Let the basic production function for the economy be $Y=A f(l) . \quad l$ is total input of labor to productive activity, and $f$ has the standard textbook properties of production functions. There are positive but diminishing returns throughout, so that $f_{l}>0, f_{l l}<0$. Assume also that $f(0)=0$ and $\lim _{l \rightarrow 0} f(0)=\infty$. To illustrate the argument as parsimoniously as possible, assume that government has no role in providing public services in and of themselves. Its only functions are to restrict the options in private production. This can be modeled by having the government be simply a dispenser of permits. $X$ is the number of such permits that exist. These can be thought of as inputs that must be purchased to enable production, even though they come at a cost of deadweight loss in production. The model is thus of rent-seeking not just as diversion of productive effort but as outright parasitism. Factors are not just diverted, but used inefficiently. One might imagine that each permit is a weight that a worker must strap to his back when entering the workplace. The permits stand for real economic phenomena 
involving artificially inefficient factor use - requirements to do business with the family members of government officials or with other firms who have also paid bribes, to pay extra for domestic products shielded from foreign competition, etc. Assume then that production once permits exist is actually $Y^{\prime} \equiv A f(l)[1-t(X)]$, where $X$ is the number of permits and $t^{\prime}>0, \mathrm{t}^{\prime \prime}<0$ and $t(0)=0$.

Permits are paid for like labor, out of produced income. And like output, they are generated by applying the only scarce resource, labor, according to $X=$ $g(e ; \alpha)$, with $g_{e}>0, g_{e e}<0 . \quad \alpha$ is a shift-parameter vector that is negatively related to the marginal productivity of effort in creating permits, so that $g_{e \alpha}<0$. It can be thought of as the extent to which social institutions mitigate against successful rent-seeking.

The economy operates under a full employment constraint:

$e+l=N$,

with $N$ the economy's labor endowment. Government is thus not a single entity that pursues some objective (e.g., maximizing welfare, payoffs to supporters or votes), but an outlet for entrepreneurial endeavor like productive activity.

Total income produced accrues either to laborers or to permit producers:

$Y=w_{e} e+w_{l} l$. 
$w_{e}$ and $w_{l}$ are the wages in each activity. They will be equal to the value of marginal product:

$w_{e}=p g_{e}($.$) ,$

$w_{l}=A f_{l}().[1-t(X)]$.

$p$ is the price of permits, measured against the numeraire, income. The model is closed by imposing the equilibrium condition that the marginal return to labor in the two activities is equal:

$w_{e}=w_{l}$

Given the exogenous $\alpha$, there are thus eight unknowns - the wage rates $w_{e}$ and $w_{l}$, the permit price $p$, total consumption $C$, total labor devoted to each activity $e$ and $l$, permits produced $X$ and output produced $Y$. Some important figures for the analysis here are the total number of permits in equilibrium $X^{*}$, the equilibrium amount of effort devoted to permit production $e^{*}$, and the loss of output relative to the equilibrium with no permits:

$\bar{Y}=A f(N)-A f\left(l^{*}\right)\left[1-t\left(X^{*}\right)\right]$ 
Note that it is possible to have a golden equilibrium in which no permits are issued $\left(e^{*}=0\right)$ and income is maximized. But given the assumptions about $f$ the contrary result is not possible. In other words, there is no possibility of a perfectly corrupt society. The economic interpretation for this result is that for at least some interval labor must be used for production so that there is some output to be distributed to permit owners. Denmark had a score of 10.0 in the 1998 TI ratings, which the organization characterizes as "perfectly corruption free." No nation, in contrast, has thus far received a score of zero. A sufficient condition for the golden equilibrium is that $g_{e}(0, \alpha)<A f_{l}(N)$. This condition is more likely as $\alpha$ is greater. If it does not hold than an interior solution obtains.

Several results follow directly from analysis of the above framework. First, corruption is a negative function of $\alpha$. Second, there will be co-movements in the equilibrium size of the state $X^{*}$ and the equilibrium amount of corruption $e^{*}$ as $\alpha$ varies. The weaker are the exogenous constraints on the productivity of permit-creation, the bigger its relative return and hence the larger the relative division of $N$ among $l$ and $e$. This result is explicitly derived in Krueger (1974), and is the central point of Tullock (1967). Thus, states with higher (lower) $\alpha$ should have both more (less) government interference and more (less) corruption. This result requires that the two variables be considered in a simultaneous framework. The idea that corruption and government are both endogenous also appears in Erlich and Lui (1999).

\section{Corruption and productivity}

Another important implication is that more technologically advanced societies 
may have less corruption, for at least one and possibly two reasons. In the usual way, technological progress in production is modeled as an increase in $A$. Totally differentiating (6) and rearranging terms yields

$$
\frac{d \bar{Y}}{d A}=f(N)-f(l)[1-t(X)]-A f(l)[1-t(X)] \frac{d l}{d A}+A f(l) \frac{d t(X)}{d X} \frac{d X}{d A}
$$

The change in $\bar{Y}$ will always have two components. The first is due to the direct opportunity cost of a given amount of rent-seeking. Output must be created using less than the full employment endowment $N$ because labor in the amount $e^{*}$ is unavailable for production because it has been diverted to creation. This distance, the diversion effect, is given by $A\left[f(N)-f\left(e^{*}\right)\right]$. This is the effect emphasized historically in the rent-seeking literature. The second source of inefficiency, the millstone effect, is caused by production away from the frontier with the smaller labor pool. It occurs because permit production destroys some part of potential income. The diversion effect moves production back along the production frontier, and the millstone effect moves the equilibrium within it.

An increase in $A$ increases the marginal return to production labor, and so labor is reallocated from $e$ to $l$. Permit production declines, and the diversion effect is unequivocally smaller, as represented in (7) by $f(l)[1-t(X)] \frac{d l}{d A}$. However, the direction of the change in the millstone effect, and hence the total loss $\bar{Y}$, is ambiguous. On the one hand less effort is being diverted from production, and fewer permits are being produced, so the tax on production $t\left(X^{*}\right)$ is smaller. In (7) this is given by 
$A f(l) \frac{d t(X)}{d X} \frac{d X}{d A}$, which can be restated as $-A f(l) \frac{d t(X)}{d X} \frac{d X}{d e} \frac{d l}{d A}$. On the other hand, the smaller fraction is being taken of greater output, and so in absolute terms it is still

possible for $\bar{Y}$ to grow. This positive effect of higher productivity on $\bar{Y}$ is given by the remaining terms in (7), $f(N)-f(l)[1-t(X)]$.

Whether or not the total amount of corruption increases or decreases because of the increase in $A$ thus becomes an empirical question, but permit production unambiguously declines. The answer depends first on the responsiveness of $g$ to changes in $e$. The more concave $g$ is, the less reallocation of $e$ will be needed to restore wage equality in the two sectors. This means that the absolute value of the diversion effect is lower and the likelihood that the total millstone effect on output, and hence the two effects combined, is negative is greater. An analogous argument holds for the concavity of $f$ : the less concave it is, the less reallocation of labor between the sectors occurs. If large, discrete changes in $A$ occur, this increases the income-destroying portion of the millstone effect, and hence makes it more likely that the deadweight loss from corruption increases. Note that this is a contrast to MSV, who find that an improvement in productivity cannot lead to an increase in appropriation.

Other than in MSV, the relation between the state of production technology and the social cost of corruption has not been emphasized in the literature. Even in MSV the establishment and strengthening of property-rights protection, which establishes the productivity of rent-seeking effort and is so important in that model, is largely unexplored. Here, nations with more advanced division of labor or production technology may have more to lose from corruption. In a society with low productivity, the effort spent seeking permits may be diverted from, for example, street peddling. But 
in an advanced society, permit-generating effort will be diverted from productive activity of far greater value owing to complex division of labor and the presence of large amounts of productivity-enhancing technology, e.g. from a semiconductor factory. It is hence is certainly more costly on a per-unit basis and may be more costly in total.

This is a significant claim because of the light it sheds on the relation between corruption and prosperity. While it is well-established that corruption harms economic growth, it is also true that increasing the gains to exchange will lower the return to corruption. Depending on the nature of the collective-choice process, the greater losses to corruption in a more productive society may result in a greater investment in its control. The stylized fact of the coincidence of prosperity and clean governance may not be simply a function of corruption deterring growth, but of lack of growth providing little motivation for investment in fighting corruption, and a great deal of motivation for engaging in it. If the model is an accurate description of the corruption process, nations with higher productivity will empirically have less corruption and will be wealthier, not just because they are more productive but because there is less deadweight loss from permit-seeking.

\section{The empirical model}

The implications

Several empirical questions arise from the above framework, beyond the most elementary one of the relation between technological advances and corruption. The first is an older controversy descended from the fatalistic Virginia school of public choice. Krueger (1974) and MSV depict a rent-seeking trap in which extensive government 
intervention raises the return to appropriation, which draws labor away from production and causes the production of yet more intervention. Government activity beyond the protection of property rights will cause more corruption. If a rent-seeking trap develops of the sort predicted by Krueger and MSV, government size will increase corruption, and corruption too will increase government spending. There is also a particular variant with respect to democracy. For example, Cheung (1998) argues that it promotes not just poor economic performance but corruption as well, as politicians auction off government favors to factions in an electorate ill-prepared to appreciate the costs of such measures.

On the other hand the Chicago school of public choice argues that governance, and democratic governance in particular, is a means to provide public services that coexist with rent-seeking in a manner that minimizes the latter. Politicians and bureaucrats are subject to competitive pressures, which may differ in type but not in fundamental nature from those of market traders. Excessively costly intervention provokes competition from political traders - electoral candidates, potential appointees to the bureaucracy, etc. - who bid down both the level of intervention and the level of bribery and other costs associated with it. In other words, political markets behave in exactly the same way as any other markets. The argument is laid out most famously in Becker (1983), and finds echoes in Olson (2000). Collective choice determines spending, which then determines lower corruption. An extension that has proven particularly influential is Wittman (1989), who argues that democracy in particular improves the competitiveness of the political process, and hence should enhance efficiency, defined not around income maximization but preferences of the citizenry. 
If the Chicago hypothesis is correct, we would expect that institutional features of societies that lower the cost of political competition - i.e., that lower $g^{\prime}$ - would lower the amount of corruption. Such features might include open immigration and emigration laws, freedom of thought (in press, speech and religion), and limits on the ability of the state to prosecute political opposition. The Wittman variant would also suggest that democratic means for deciding political power should promote more effective corruption control.

The two schools of thought also have different implications for the meaning of government spending. In Virginia-school thinking it is simply rents successfully sought, while in Chicago-school thinking it is something that arises from public desires for social insurance, construction of public goods or other widely desired goals beyond propertyrights protection.

The dynamics of government size over time are themselves the subject of an extensive empirical literature. The claim that national per capita income increases demand for government spending, regulation and production has been investigated a number of times. Among the papers that investigate the growth of spending, a key controversy is whether the demand for such spending is income-elastic. While the growth of government spending as countries have gotten wealthier has been noted in the past (Peltzman, 1980), the large empirical literature on whether the latter causes the former is mixed. For example, Kolluri et al. (2000) and Thornton (1999) find that it does and Afxentiou and Serletis (1996 IEJ) find otherwise. In any event, the theory is sufficiently entrenched to indicate that any empirical model in which government 
spending is a left-hand variable indicates that per capita income be included on the righthand side.

The Empirical Specification

Several versions of the following basic simultaneous empirical model are used to test the above implications:

$$
\begin{aligned}
& \text { CORRUPTION }=a_{0}+a_{1} \text { GOV }+a_{2} \text { PCS }+a_{3} \text { OPEN }+a_{4} \text { COMPETITION }+ \\
& a_{5} \text { FRACTION }+a_{6} \text { CULTURE } \\
& \text { GOV }=b_{0}+b_{1} \text { CORRUPTION }+b_{2} \text { PCGDP }+b_{3} \text { POLRIGHTS }+ \\
& \quad b_{4} \text { URBAN }+b_{5} \text { AVGSCHOOL } \\
& \text { PCGDP }=c_{0}+c_{1} \text { CORRUPTION }+c_{2} \text { PCS }
\end{aligned}
$$

The estimation is by three-stage least squares. CORRUPTION is the sum of two World Bank measures of governance quality, “corruption control” and "rule of law," for 2002. These survey-based data are available at http://info.worldbank.org/governance/kkz2002/tables.asp. A higher number denotes better governance. $G O V$ is government consumption spending as a fraction of GDP, which is a proxy for rent-seeking in Virginia-school thinking and a desired outcome of collective choice, to be protected from the impact of corruption, in Chicago-school theory. $P C S$ is the number of personal computers per 1000 population in 2000 , and proxies for $A$. It is from the World Bank's World Development Indicators. OPEN is 
imports plus incoming foreign direct investment as a percentage of GDP. It is included on the assumption that more pressure from globalization of the economy results in endogenously better governance.

COMPETITION is a combination of two variables that measure how easy it is to bring political pressure to bear to lower corruption. POLRIGHTS is the Freedom House measure of political rights, which ranges from one to seven, with one denoting the most freedom. This variable is widely used in empirical work, but for present purposes it is worth investigating it in some detail. A country's rating depends on the extent to which public officials are chosen by election, whether electoral competition is meaningful, whether elected officials have significant power, whether citizens can organize into effective political groups, whether the country is free from domination by traditional or military hierarchies, and whether minorities have self-governance and/or substantial participation in government. INFOSOC is the 2003 compilation of a measure created by Norris (2001, Table 3.2) of the combination of old and new media available in a country - of the penetration of newspapers, radio, television and stationary and mobile telephones plus the percentage of the population that regularly uses the Internet, the percentage that uses personal computers and the number of Web hosts.

POLRIGHTS and INFOSOC measure two different aspects of the cost of changing government policy, including anti-corruption efforts. The former measures the cost to citizens of opposing a policy once they have made a decision on its merit, and the latter measures how costly it is to gain the information necessary to make the decision. ${ }^{4}$

4. The argument that freedom of thought, i.e. of speech, religion and the press, is a way to make information markets more competitive has been made by Posner (2003). 
Because it is more narrowly defined, INFOSOC is a superior arrangement than Freedom House's companion measure to POLRIGHTS, which measures civil liberties and is widely used in other work. While the civil-liberties measure is partly based on "freedom of expression, assembly, association, education, and religion, it also incorporates a "generally equitable system of the rule of law." ${ }^{5}$ It is thus best seen as a measure of both an input and an output in the framework here.

FRACTION is the combination of the measures of ethnic, linguistic and religious fractionalization generated by Alesina (2003). If greater tribal fractionalization raises the costs of coordination across tribal lines to fight corruption or facilitates the creation of smaller tribally defined groups around which to organize, greater fractionalization can in the framework here increase the marginal productivity of permit-production effort. ${ }^{6}$ That paper finds that, on a simple correlation basis, this index is positively correlated with corruption. Finally, CULTURE stands for vectors of cultural dummies that attempt to account for global differences in preferences that might make corruption more or less undesirable. While the model assumes that corruption is undesirable because it lowers income, it is possible that corrupt practices yield offsetting utility. Such a cultural source for corruption has been theoretically posited by Huang and Wu (1994) and Montaner (2000), though theoretically discounted by Paldam (2002). There are three attempts to measure such differences, based on geography, colonial heritage or modal religion. Dummies are included in the first specification for sub-Saharan Africa, Spanish-speaking

5. Quoted descriptions are from Freedom House (2003).

6. For an analysis of widespread tribal fractionalization proving productive for rentseeking in India see Osborne (2001). 
Latin America, the former Soviet Union and members of the Arab League. The second specification includes dummies for Anglo-American, French or Iberian colonial heritage. The third uses dummies taking the value one if the modal religion is Protestant Christianity (including Anglicanism), Catholicism or Islam, the three religions with sufficient representation in the data set to merit inclusion. PCGDP and URBAN are the 2000 values of per capita income and the percentage of the population that is urban, from the WDI.

(8a) includes, in addition to the causation from government to corruption posited by the rent-seeking literature, three elements of $\alpha$ - political competition, information production and fractionalization. $P C S$ measures $A$. If the MSV model is correct it should be positively signed. In addition to including the amount of government spending to test for the simultaneous rent-seeking trap, (8b) contains variables recommended by some of the growth-of-government literature, which contends that public spending expands in higher-income and more urbanized (Peltzman, 1980; Kau and Rubin, 2002) nations. (8c) is the equation for equilibrium income, $A f\left(l^{*}\right)\left[1-t\left(X^{*}\right)\right]$.

Results are reported in Table 1. Because INFOSOC and POLRIGHTS are highly correlated ( $\rho=-.5870$ ), a model without POLRIGHTS in (8a) is also reported for each cultural specification. With respect to the prime issue raised in the above analysis, in all specifications a higher level of technological productivity is associated with less corruption. Other issues are clarified as well. The result of Alesina (2003) is somewhat robust to the extension here, in that FRACTIONALIZATION is significant at at least the ten-percent level in five of the six specifications. POLRIGHTS is significant in all specifications in which it is included. 
The results of the variables representing the competitiveness of political markets are striking. In the specifications with both variables POLRIGHTS is significant in the expected direction while INFOSOC is only significant (in the expected direction) once, when it is the only political-market competition variable included. This result suggests that political competition is extremely important in promoting better governance, and that information sufficient to allow citizens to agitate for it prevails even when penetration of new and old media is not particularly pronounced. It may be that the necessary information about corruption's nature, scope and particulars can emerge even without such conventional measures of its availability, so that the means to act on the information is of primary importance. Political markets, in other words, can function well (at least with respect to corruption) even when the market size of the formal informationgenerating industry is not large.

As for the cultural dummies, the only constant finding is that LATIN is significant and negatively signed. Religious and colonial-heritage variables are never significant. Nations with Latin backgrounds tend to have more than the expected amount of corruption, other things equal. Figure 3 plots the actual amount of corruption versus what would be expected without the Latin penalty for Latin countries in the data set, i.e. the predicted value from the structural-form estimation of (8a) in the full specification without accounting for the Latin dummy. The average Latin country in the sample is 45.3 percent more corrupt than would be expected $(n=9)$. This anomaly, the only consistent cultural result, remains to be explained. Other than that, corruption appears to be a phenomenon of income maximization rather than intrinsic preferences. 


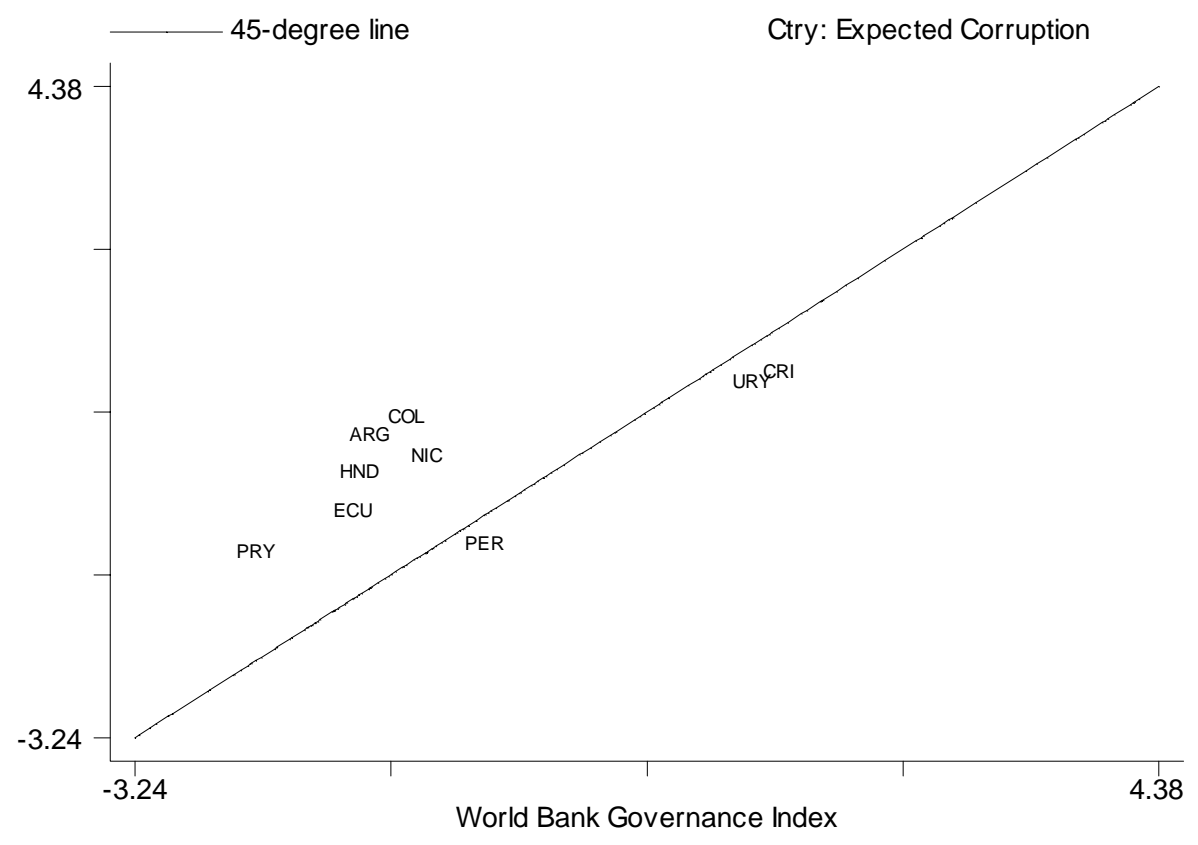

Figure 3 - Expected corruption for Latin nations.

Also of interest is the failure to confirm the standard version of the rent-seeking model as it applies to government spending. Both corruption and government spending are typically significant in the simultaneous framework. But unlike rent-seeking theory predicts, the signs are positive. The quality of governance is always a positive and significant predictor of the amount of spending, while spending is in three of six specifications a significant predictor of quality of governance. In other words, nations that have greater government spending tend to spend more on corruption control for a given level of productivity, and nations with better governance are willing to engage in more government spending. This suggests that government spending grows for reasons external to corruption, but if it is bigger because of social preferences then societies may find it worthwhile to invest more in corruption control, a topic explored in Section 4 below. The results, combined with the positive effect of more effective political competition on corruption control, provides support for optimistic models of political 
competition generally and electoral competition in particular as means to control the deadweight losses of government spending.

\section{Interpretation and Speculation}

The results are suggestive on a number of counts with respect to the causes and effects of corruption. One finding is that the relation between corruption and government spending is the opposite of what traditional models of rent-seeking would predict if the former is an output of the latter, other things equal. In addition, Fig. 1 suggests that wealthy nations that devote large percentages of national income to extensive welfare states are also among the least corrupt. That is a phenomenon that begs explanation. Given that large amounts of income are transferred via the government in such programs as state pensions and health-care systems, why are these societies, with so many tempting rent-seeking targets, not more corrupt than they are? The answer may be that large government spending, particularly in an advanced society, carries a corruption penalty that is too high. If corruption also causes each unit of government spending to be subject to corruption-induced waste, more corruption implies that these costs, too, are greater. It is then easier to justify spending more resources on the prevention of such waste by greater enforcement of property rights. The role of an independent judiciary as suggested by Landes and Posner (1975) provides one plausible means of corruption control, although the lack of any measures of judicial independence prevents a direct test of an association between government spending and such independence.

The findings may also explain what has come to be known as the "Tullock paradox.” Rent-seeking scholars have puzzled for years over the seemingly small 
amount of rent-seeking expenditures relative to the size of the rents being sought. Most of the evidence has been anecdotal, with Tullock himself (1997) citing a large number of examples from the U.S. But societies that invest a great deal in the rule of law both lower the returns to rent-seeking and insure that the rents that are parceled out are more stable, thus discouraging endless cycles of rent-seeking warfare. While the paradox has always focused on the seemingly implausibly high benefit/cost ratios for the winners in a vigorous rent-seeking market, it is worth remembering that for every winner there may be many losing pressure groups. Strategies that raise $\alpha$ will also cause each of these groups to spend few resources in its unsuccessful efforts. The most important effect of cleaner governance is thus to insure that the combined amount spent by winners and losers is small.

The results also suggest that there is an under-emphasized dynamic and endogenous aspect to corruption. While it is surely true that corruption hampers economic growth, it is also true that rapid growth and rising prosperity increase the social cost of corruption. If the market for governmental authority is at least somewhat competitive, whether via elections or not, then as nations prosper their political systems should begin to weed out the most corrupt practices accordingly. If $\alpha$ is lowered over time by such a Becker (1983)-type competitive process, the relatively high amount of corruption in poorer societies may be due not just to the deleterious effects of corruption on growth but to the fact that the costs, political and otherwise, of the investments needed to protect against it are not yet justified by the benefits. If education, modern technology efficiently applied and the division of labor advance sufficiently rapidly to enable rapid growth then the 
corruption tax may grow so costly that political competition overcomes the inertia of existing rent-seeking pressures and brings about political changes to reduce it. If not countries may stagnate in the rent-seeking trap.

History is replete with anecdotes of better governance and prosperity coinciding. While he does not make the connection, Barzun (2000) notes that Venice was by a substantial margin the best-governed state in late-Renaissance Europe, even as it was the most commercial. The puzzle of governance in Renaissance Italy has also drawn the attention of Putnam (1993). Southern Italy was governed vertically, with a feudal hierarchy extending down from the king, while Northern Italy was governed horizontally, with mutual defense pacts between relatively equal community associations. But the usual assumption is that causation runs from government structure to prosperity - better governance led to more wealth creation. However corruption control, with its enforcement requirements and the need to provide adequate compensation to civil servants, is not free, and its cost may have to be justified for a welfare-maximizing government to find it worthwhile.

The pattern of corruption may well have an endogenous timeline as a country industrializes, just as income distribution has been demonstrated to have (Kuznets, 1968). There may be a takeoff point for anti-corruption efforts that is analogous to and indeed may trail by some consistent margin the better-known takeoff stage in industrialization. Once there is a widespread introduction of enough productivity-enhancing shocks the two effects of cleaner governance enhancing growth and higher productivity enhancing corruption control may 
reinforce one another. Anecdotal evidence on societies suddenly making substantial efforts to control corruption is common. Singapore and Hong Kong, which are now thought of as model states with respect to corruption control, were actually quite corrupt until reforms were launched in the mid-1960s in the former case and the early 1970s in the latter, after rapid growth had begun but well before it had ended. Similar launches of anti-corruption efforts have been documented for the United Kingdom, the first industrial power, in the mid-nineteenth century and for the U.S. later in that century (Rose-Ackerman, 1999). If the dating of these efforts is accurate it appears that they all occurred after the industrialization process was well underway. Miwa and Ramseyer (2000) present an example from the other side in which Japanese firms in the early twentieth century, when industrialization was still young, established arbitration procedures to avoid a very corrupt judiciary.

The ability to use government to transfer wealth is in some sense instability in property rights, in that the right to use property in exchange is constrained. The firm that requires a license to import (especially if it must pay a bribe to get one) finds its ability to exchange resources it owns in voluntary exchange for that import limited and more costly. The domestic monopolist protected by bribes lowers the purchasing ability of the labor time of its customers. The problem of corruption control may be just an example of the broader Demsetz (1967) analysis of property rights evolving only when the benefits to establishing them justify the costs of enforcing them. 


\section{Conclusion}

Development is about dynamics and transformation. Thus how corruption might evolve over time is a question of great interest. The introduction of modern technology and economic organization brings with it all manner of well-known changes - migration to the cities, declining fertility, etc. The cost of corruption is something else that changes over time. Raising the relative return to production may cause an endogenous decrease in rent-seeking activity. Further, if government officials have self-interest that promotes corruption but the society as a whole has an interest in controlling it, these two functions trade off. That corruption is a negative function of the cost of creating opportunities for it is a central finding of this paper. The implication is that policies that promote productivity, e.g. improvements in education and public health or liberalized economies, can generate incentives for investing in the rule of law. This is in no way to diminish the importance of organized anti-corruption campaigns in poor countries, but just as with environmental and safety regulation in there are limits to the ability of the state to achieve goals by passing laws, limits that are much more compelling in impoverished nations.

\section{References}

Afxentiou, Panos C. and Serletis, Apostolos. “Government Expenditures in the European Union: Do They Converge or Follow Wagner's Law?” International Economic Journal 10 (3), Autumn 1996, 33-47. 
Alesina, Alberto. “Fractionalization.” Journal of Economic Growth 8 (2), June 2003, 155-94.

Barreto, Raul A. “Endogenous Corruption in a Neoclassical Growth Model.” European Economic Review 44 (1), January 2000, 35-60.

Barzun, Jacques. From Dawn to Decadence: 500 Years of Western Cultural Life, 1500 to the Present. New York: Harper Collins, 2001.

Becker, Gary S. “A Theory of Competition Among Pressure Groups for Political Influence.” Quarterly Journal of Economics 98 (3), August 1983, 371-400.

Cheung, Steven N.S. “The Curse of Democracy as an Instrument in Collapsed Communist Economies.” Contemporary Economic Policy 16 (2), April 1998, 247-249.

Demsetz, Harold. “Toward a Theory of Property Rights.” American Economic Review 57 (2), May 1967, 347-359.

Ehrlich, Isaac and Lui, Francis T. "Bureaucratic Corruption and Endogenous Economic Growth.” Journal of Political Economy 107 (6), December 1999, S270-S293. Freedom House. Freedom in the World 2003: The Annual Survey of Political Rights and Civil Liberties. New York: Freedom House, 2003.

Hirshleifer, Jack. “The Paradox of Power.” Economics and Politics 3 (3), November 1991, 177-200

Huang, Peter H., and Wu, Ho Mou. "More Order Without More Law: A Theory of Social Norms and Organizational Cultures.” Journal of Law, Economics and Organization 10 (2), October 1994, 390-406.

Kau, James B. and Rubin, Paul H. “The Growth of Government: Sources and Limits.” Public Choice 113 (3-4), December 2002, 389-402. 
Kolluri, Bharat R., Panik, Michael J. and Wahab, Mahmoud S. "Government Expenditure and Economic Growth: Evidence from G7 Countries.” Applied Economics 32 (8), June 2000, 1059-68.

Krueger, Anne O. "The Political Economy of the Rent-Seeking Society.” American Economic Review 64 (3), June 1974, 291-303.

Kuznets, Simon. Toward a Theory of Economic Growth, With Reflections on the Economic Growth of Modern Nations. New York: Norton, 1968.

Landes, William M. and Posner, Richard A. "The Independent Judiciary in an Interest-Group Perspective.” Journal of Law and Economics 18 (3), December 1975, 875-901.

Mauro, Paolo. “Corruption and Growth.” Quarterly Journal of Economics 110 (3), August 1995, 681-712.

Miwa, Yoshiro and Ramseyer, J. Mark. "Corporate Governance in Transitional Economies: Lessons from the Prewar Japanese Cotton Textile Industry.” Journal of Legal Studies 29 (1), January 2000, 171-204.

Mo, Pak Hung. "Corruption and Economic Growth.” Journal of Comparative Economics 29 (1), March 2001, 66-79.

Mohtadi, Hamid and Roe, Terry L. "Democracy, Rent Seeking, Public Spending and Growth.” Journal of Public Economics 87 (3-4), March 2003, 445-66.

Montaner, Carlos Alberto. "Culture and the Behavior of Elites in Latin America.” In Lawrence E. Harrison and Samuel P. Huntington (eds.), Culture Matters : How Values Shape Human Progress. New York: Basic Books (2000), 56-64. 
Murphy, Kevin M., Shleifer, Andrei and Vishny, Robert W. "Why is RentSeeking so Costly to Growth?” American Economic Review 83 (2), May 1993, 409-14. Norris, Pippa. The Digital Divide: Civic Engagement, Information Poverty, and the Internet Worldwide. New York: Cambridge U. Press, 2001.

Osborne, Evan. "Culture, Development, and Government: Reservations in India." Economic Development and Cultural Change 49 (3), April 2001, 659-685.

Olson, Mancur. Power and Prosperity: Outgrowing Communist and Capitalist Dictatorships. New York: Basic Books, 2000.

Paldam, Martin. “The Cross-Country Pattern of Corruption: Economics, Culture and the Seesaw Dynamics.” European Journal of Political Economy 18 (2), June 2002, $215-40$.

Peltzman, Sam. “The Growth of Government.” The Journal of Law and Economics 23 (2), October 1980, 209-287.

Posner, Richard A. Economic Analysis of Law. New York: Aspen Publishers (2003).

Putnam, Robert D. “What makes democracy work?” National Civic Review 82 (2), Spring 1993, 101-107.

Rose-Ackerman, Susan. Corruption and Government: Causes, Consequences and Reform. Cambridge, U.K.: Cambridge University Press, 1999.

Tanzo, Vito, and Davoodi, Hamid. “Corruption, Public Investment and Growth.” In Viti Tanzo (ed.), Policies, Institutions and the Dark Side of Economics. Northampton, MA: Elgar (2000), 154-70. 
Thornton, John. “Cointegration, Causality and Wagner's Law in $19^{\text {th }}$ Century Europe.” Applied Economics Letters 6 (7), July 1999, 413-416.

Tullock, Gordon. "The Welfare Costs of Tariffs, Monopolies and Theft.”

Western Economic Journal 5 (3), June 1967, 224-32.

Tullock, Gordon. “Where is the Rectangle?” Public Choice 91 (2), April 1997, 149-59.

Wittman, Donald. "Why Democracies Produce Efficient Results.” Journal of Political Economy 97 (6), December 1989, 1395-424. 
Table 1

Regression Results Geography as culture With POLRIGHTS

\begin{tabular}{|c|c|c|c|c|c|}
\hline WBSUM & & GOV & & PCGDP & \\
\hline INTERCEPT & $\begin{array}{l}-1.418555 \\
(-1.28)\end{array}$ & $\overline{I N T E} R C E P T$ & $\begin{array}{l}15.38464 * * * \\
(5.76)\end{array}$ & $\overline{I N T E R C E P T}$ & $\begin{array}{l}5502.004^{* * *} \\
(8.38)\end{array}$ \\
\hline$G O V$ & $\begin{array}{l}.1296418 * \\
(2.03)\end{array}$ & WBSUM & $\begin{array}{l}3.891733 * * * \\
(3.45)\end{array}$ & $P C S$ & $\begin{array}{l}29.84462 * * * \\
(4.48)\end{array}$ \\
\hline$P C S$ & $\begin{array}{l}.006269 * * * \\
(4.23)\end{array}$ & $P C G D P$ & $\begin{array}{l}-.0006735^{* *} \\
(-2.61)\end{array}$ & WBSUM_ & $\begin{array}{l}2272.393^{* * * *} \\
(4.16)\end{array}$ \\
\hline OPEN & $\begin{array}{l}-.0027672 \\
(-1.11)\end{array}$ & POLRIGHTS & $\begin{array}{l}.0537489 \\
(0.14)\end{array}$ & & \\
\hline FRACTION & $\begin{array}{l}-.3747026^{*} \\
(-2.20)\end{array}$ & $U R B A N$ & $\begin{array}{l}.0854309 * \\
(2.22)\end{array}$ & & \\
\hline INFOSOC & $\begin{array}{l}.0133384 \\
(1.16)\end{array}$ & & & & \\
\hline POLRIGHTS & $\begin{array}{l}-.1890665 * \\
(-2.24)\end{array}$ & & & & \\
\hline$A F R I C A$ & $\begin{array}{l}.1708384 \\
(0.60)\end{array}$ & & & & \\
\hline$A R A B$ & $\begin{array}{l}.414682 \\
(0.92)\end{array}$ & & & & \\
\hline LATIN & $\begin{array}{l}-.8088764 * * \\
(-3.17)\end{array}$ & & & & \\
\hline USSR & $\begin{array}{l}-1.007727 * * \\
(-2.83)\end{array}$ & & & & \\
\hline$R^{2}$ & .8272 & & .1059 & & .8913 \\
\hline$X^{2}$ & $416.1654 * * *$ & & $27.14104 * * *$ & & $568.0146^{* * *}$ \\
\hline$N$ & 69 & & & & \\
\hline & & Without $P$ & IGHTS & & \\
\hline WBSUM & & $\mathrm{GOV}$ & & PCGDP & \\
\hline$\overline{I N T E R C E P T}$ & $\begin{array}{l}-3.382208 * * * \\
(-3.19)\end{array}$ & $\overline{I N T E} R C E P T$ & $\begin{array}{l}18.79233^{* * *} \\
(11.03)\end{array}$ & INTERCEP & $\begin{array}{l}5561.989 * * * \\
(8.49)\end{array}$ \\
\hline$G O V$ & $\begin{array}{l}.2010441^{* *} \\
(2.68)\end{array}$ & WBSUM & $\begin{array}{l}34.435863 * * * \\
(4.12)\end{array}$ & $P C S$ & $\begin{array}{l}29.02824 * * * \\
(4.37)\end{array}$ \\
\hline$P C S$ & $\begin{array}{l}.0044369 * \\
(2.55)\end{array}$ & $P C G D P$ & $\begin{array}{l}-.0008045^{* *} \\
(-3.27)\end{array}$ & WBSUM_ & $\begin{array}{l}2343.126^{* * * *} \\
(4.30)\end{array}$ \\
\hline OPEN & $\begin{array}{l}-.002575 \\
(-1.01)\end{array}$ & POLRIGHTS & $\begin{array}{l}-.3253623 \\
(-1.01)\end{array}$ & & \\
\hline FRACTION & $\begin{array}{l}-.256598 \\
(-1.36)\end{array}$ & $U R B A N$ & $\begin{array}{l}.0651084 * \\
(1.78)\end{array}$ & & \\
\hline INFOSOC & $\begin{array}{l}.0277866 * \\
(1.99)\end{array}$ & & & & \\
\hline$A F R I C A$ & $\begin{array}{l}.1075546 \\
(0.35)\end{array}$ & & & & \\
\hline$A R A B$ & $\begin{array}{l}-.0699911 \\
(-0.17)\end{array}$ & & & & \\
\hline LATIN & $\begin{array}{l}-.6418411^{*} \\
(-2.13)\end{array}$ & & & & \\
\hline USSR & $\begin{array}{l}-.8740332 * \\
(-2.38)\end{array}$ & & & & \\
\hline$R^{2}$ & .6932 & & .0061 & & .8903 \\
\hline$X^{2}$ & $213.0734 * * *$ & & $36.47703 * * *$ & & $568.9656 * * *$ \\
\hline
\end{tabular}


Table 1 (continued)

Colonial heritage as culture

With POLRIGHTS

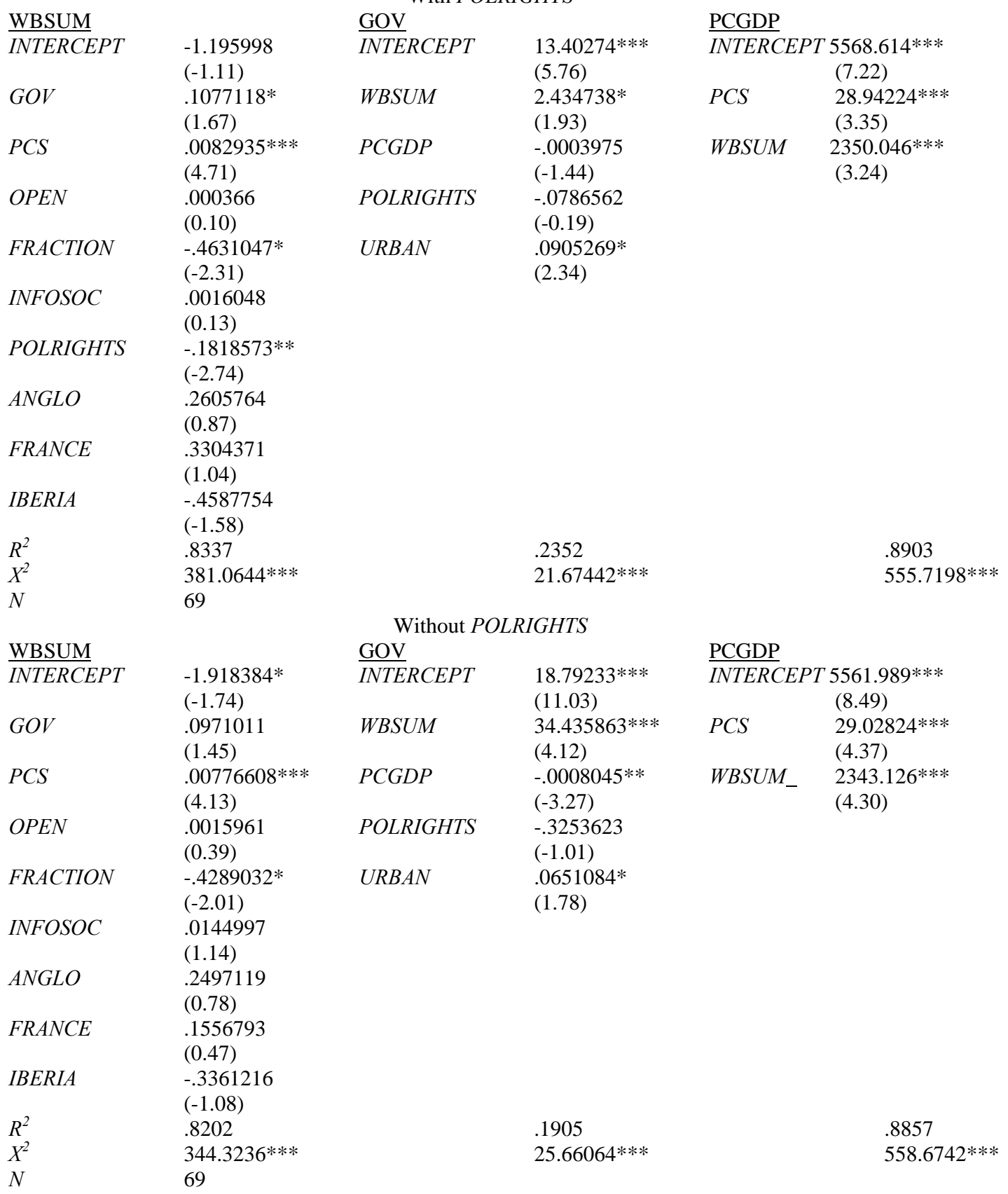




\begin{tabular}{|c|c|c|c|c|c|}
\hline \multicolumn{6}{|c|}{$\begin{array}{c}\text { Table } 1 \text { (continued) } \\
\text { Religion } \\
\text { With POLRIGHTS }\end{array}$} \\
\hline WBSUM & & $\underline{\mathrm{GOV}}$ & & PCGDP & \\
\hline INTERCEPT & $\begin{array}{l}-.7609738 \\
(-0.59)\end{array}$ & $\overline{I N T E R C E P T}$ & $\begin{array}{l}12.87168 * * * \\
(5.76)\end{array}$ & $\overline{I N T E R C E P}$ & $\begin{array}{l}5614.329 * * \\
(6.95)\end{array}$ \\
\hline$G O V$ & $\begin{array}{l}.0720183 \\
(0.84)\end{array}$ & WBSUM & $\begin{array}{l}2.030967 * \\
(1.93)\end{array}$ & $P C S$ & $\begin{array}{l}28.32376^{* * *} \\
(3.07)\end{array}$ \\
\hline$P C S$ & $\begin{array}{l}.0086001 * * * \\
(5.04)\end{array}$ & $P C G D P$ & $\begin{array}{l}-.0003246 \\
(-1.44)\end{array}$ & WBSUM & $\begin{array}{l}2403.163 * * \\
(3.09)\end{array}$ \\
\hline OPEN & $\begin{array}{l}.0018012 \\
(0.51)\end{array}$ & POLRIGHTS & $\begin{array}{l}-.1206088 \\
(-0.30)\end{array}$ & & \\
\hline FRACTION & $\begin{array}{l}-.3019184 * \\
(-1.77)\end{array}$ & $U R B A N$ & $\begin{array}{l}.0926311^{*} \\
(2.31)\end{array}$ & & \\
\hline INFOSOC & $\begin{array}{l}.0055977 \\
(0.44)\end{array}$ & & & & \\
\hline POLRIGHTS & $\begin{array}{l}-.209615^{*} \\
(-2.49)\end{array}$ & & & & \\
\hline CATHOLIC & $\begin{array}{l}-.3171243 \\
(-1.10)\end{array}$ & & & & \\
\hline PROTESTANT & $\begin{array}{l}-.3725017 \\
(-0.97)\end{array}$ & & & & \\
\hline ISLAM & $\begin{array}{l}.2875778 \\
(0.57)\end{array}$ & & & & \\
\hline$R^{2}$ & .8484 & & .2525 & & .8895 \\
\hline$X^{2}$ & $398.3437 * * *$ & & $21.19363 * * *$ & & $551.5256 * * *$ \\
\hline$N$ & 69 & & & & \\
\hline & & Without $P$ & IGHTS & & \\
\hline WBSUM & & $\mathrm{GOV}$ & & PCGDP & \\
\hline$\overline{I N T E R C E P T}$ & $\begin{array}{l}-3.047503^{*} \\
(-2.46)\end{array}$ & $\overline{I N T E} R C E P T$ & $\begin{array}{l}18.79233 * * * \\
(11.03)\end{array}$ & $\overline{I N T E R C E P}$ & $\begin{array}{l}5561.989 * * * \\
(8.49)\end{array}$ \\
\hline$G O V$ & $\begin{array}{l}.1570492 \\
(1.56)\end{array}$ & WBSUM & $\begin{array}{l}34.435863^{* * * *} \\
(4.12)\end{array}$ & $P C S$ & $\begin{array}{l}29.02824 * * * \\
(4.37)\end{array}$ \\
\hline$P C S$ & $\begin{array}{l}.0066399 * * \\
(3.15)\end{array}$ & $P C G D P$ & $\begin{array}{l}-.0008045^{* *} \\
(-3.27)\end{array}$ & WBSUM_ & $\begin{array}{l}2343.126^{* * * *} \\
(4.30)\end{array}$ \\
\hline OPEN & $\begin{array}{l}.0015362 \\
(0.42)\end{array}$ & POLRIGHTS & $\begin{array}{l}-.3253623 \\
(-1.01)\end{array}$ & & \\
\hline FRACTION & $\begin{array}{l}-.1787926 \\
(-1.01)\end{array}$ & $U R B A N$ & $\begin{array}{l}.0651084^{*} \\
(1.78)\end{array}$ & & \\
\hline INFOSOC & $\begin{array}{l}.019743 \\
(1.26)\end{array}$ & & & & \\
\hline CATHOLIC & $\begin{array}{l}-.1133079 \\
(-0.35)\end{array}$ & & & & \\
\hline PROTESTANT & $\begin{array}{l}-.3263573 \\
(-0.83)\end{array}$ & & & & \\
\hline ISLAM & $\begin{array}{l}.0645997 \\
(0.14)\end{array}$ & & & & \\
\hline$R^{2}$ & .7539 & & 1992 & & .8868 \\
\hline$X^{2}$ & $207.8016^{* * *}$ & & $23.51664 * * *$ & & $5583.3751 * * *$ \\
\hline$N$ & 69 & & & & \\
\hline
\end{tabular}

